\title{
Case Studies in the Culture of Professional Football Players and Mental Welfare and Wellbeing
}

\author{
Michael Bennett
}

\subsection{Introduction}

There is growing concern about mental health and well-being in football (soccer) and in many other areas of the increasingly competitive world of top-level sport. Statistics abound but there has been little attempt to understand the values (positive and negative) held by the players themselves in relation to their sport and how these interact with those of the clubs by which they are employed to and the impact on their mental health.

This chapter draws on the findings from a series of in-depth interviews I carried out with 12 professional football players about their experience and interpretation of mental health. The study was informed by my own experience as a professional player. It has also been guided by two sources that (as I discuss further below) I have found helpful in understanding and working through the issues highlighted by the study. The first is the ([1], p. 32) 'front stage/backstage' distinction [1], the distinction between what is performed out there, as it were, on the front stage of our lives and the personal meanings and values we embrace in the backstage. The second main guide for the study is the ([2], p. 4). Understood through Du Bois' work, the study explores the veils used by professional players to transcend their experience of being objectified — of being subject to gendered, racialised and other forms of dehumanisation - and denied a legitimate lived experience, an authentic heard voice.

The extracts that follow describe in the words of the players themselves one of four emerging themes from the interviews, called by one of the interviewees Snowing Balling of Self. In work of this kind, it is clearly impossible to divorce the

\footnotetext{
M. Bennett $(\bowtie)$

The Professional Footballers Association, Manchester, UK

University of East Anglia, Norwich, UK

(C) The Author(s) 2021

D. Stoyanov et al. (eds.), International Perspectives in Values-Based Mental

Health Practice, https://doi.org/10.1007/978-3-030-47852-0_38
} 
way the findings are understood from one's own values. Hence, before describing players' experiences of 'the snow ball effect', I will outline my own values and how these have been shaped by the culture of professional football.

\subsection{My Cultural Values}

As an ex-professional football, now an academic researcher and Director of Player Welfare at the Professional Footballers Association, I have become aware of the complexity of the different values I carry from my personal life as a black man, a married man, a Christian man and a therapist. I am also aware that these are the cultural values that have been taken from me in the world of football, described by Rhoden [3] as the values that reduce black men in sport to a property.

I am aware further of the reflective insights my counselling and my Christianity give me about my cultural and spiritual values, beyond that which is fixed by being a man, by being black and by working in the professional context of sport. In sport, feelings are denied and one has a single identity, as a player, a commodity with decreasing value because of one's age and the loss of body functions [4]. In looking beyond the physical, my spiritual and other cultural values have become crucial to my work and the work that I enjoy. These values and cultures are rarely exposed in the professional setting of football as they are taken to denote vulnerability and weakness. In these cultural encounters, I hold onto my own 'mask', as the ([5], p. 11). I want the dignity of this mask and not to feel that I have to hold a 'mask' to be accepted. I am aware of my spiritual mask, of my veil, in terms of how I see beyond the culture in the room and the values that individuals bring to the room.

The culture of sport, the culture that takes away your values and your individuality, that requires you to give up your values and individuality in order to be accepted, has been an important part of my liberation, to be accepted for who I am as opposed to who I was in the football world. This is where I find the work of ([2], p. 4) helpful. His concept of 'veils' helps me to transcend the professional culture of sport and see and understand how people give meaning to their world. This is important to me. It enables me to observe and evaluate and to see beyond my maleness to engage as a person with a distinct individual identity.

These are the cultural values that have taken my individuality from me in the world of football, the cultural values that can reduce men in sport to a property. I see similar values in the research world in which there is a culture of being accepted if you are academic and bright; and I see similar values in the world of mental health, the values of being seen as normal or abnormal. I position my own values as the search for equality, for equity and for being heard as Michael, not Mickey, a player once owned by a club and told what to do and when to do it. I see the values of research and academic institutions where you told not how to play but to write, how to be heard. In this I seek guidance from the values, Mandela [6] in seeing beyond the racial demands that lead to anger in me, I use the culture of my life in the church, one that is based on seeing beneath the stereotype. 


\subsection{The Snow Ball Effect and Its Components}

As noted above, the concept of the 'Snow Ball effect' was named as such by one of the interviewees in my study. I will call the player in question 'Billy'. I describe the Snow Ball effect in Billy's own words below. The Snow Ball effect was also one of four major themes that emerged from the interviews as a whole using a method of qualitative analysis, Smith [7] This method of analysis defines 'super-ordinate themes' (the snow ball effect being one of these) and their respective sub-elements (called 'clustered subsidiary themes'). The quotes that follow illustrate in the words of the players themselves, first the superordinate theme of the Snow Ball effect, and then four of its 'clustered subsidiary themes'. These are summarised diagrammatically in the Fig. 38.1.

\subsubsection{The Snow Ball Effect}

Billy-I likened it to a snowball effect, I started at CM and did well and the snowball grew, your then bought by a premier league club for $£ 2$ million and your snowball grows again and you're playing in the premier league and you get sold to another premier league club for $£ 4$ million you win the league cup and get called up to the National team and your snowball is a giant and I'm invincible and I'm untouchable and nothing can happen to me and I'm so confident and my ego's huge and then it comes crashing down were I have this traffic accident. A lot of time goes by with memory loss and I'm trying to get back onto my feet my balance and coordination is slowly rebuilding.

\subsubsection{Learning to Deal With and Deny Pressure}

Michael-So, my first loan spell at division 2 club was a fantastic time and probably my favourite time down there I was 17 and not long out of school I moved down there with RM and JO and spent most of year in a hotel and looking back on it, it was quite tough. Just getting first team football was quite important and learning to deal with and deny the pressures of fighting to pay the mortgages and people learning to pay their rent was quite interesting.

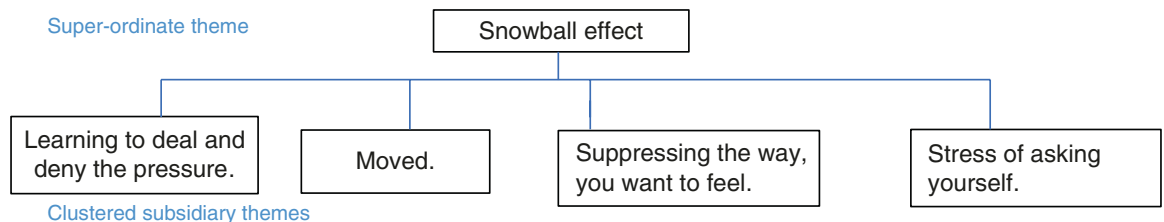

Fig. 38.1 Elements of the 'Snowball effect' 


\subsubsection{Moved}

Holly_In SG the time I was out there was when I encountered my first mental health issues. For me it was like several life stresses all came at one time and I developed some sort of anxiety and depression for around 8-10 months.

\subsubsection{Suppressing the Way You Want to Feel}

Mark-Well I made sure I didn't cry because of the way banter was in football and the kind of player I was. I was kind of looked at as a tough player so you 'hold back' and your 'pushing down your feeling basically' your "suppressing the way you want to feel" I didn't go to speak to anyone, I just remember sitting there watching games thinking I wish I wasn't injured and I wish I wasn't here. 'There was no one to reach out to', 'there was no one there', 'there was nothing'.

\subsubsection{Stress of Asking Yourself}

Charlie-So yes, it's a lot of pressure, and emotional pressure and the stress of asking yourself did I do good at this did I do good at that ...... it's constantly on your mind. I was always that person who over thought stuff. Did I do good here, or, should I do this and that better?

\subsection{The Culture and Values of Football}

These narratives reveal an emerging value and culture co-existing inside the coldness of the culture of sport, a detachment and a failure to recognise its damaging impact on players. Their ego is eroded as they attempt to rebuild themselves in isolation. They learn to be in and part of a culture in which they develop an approach of 'learning to deny and deal with pressure'. Their profession as footballers is one in which they show their feelings in phrases such as 'developed some sort of anxiety and depression'. Such phrases are not a reflection of a clinical culture of 'selfdiagnosis'. They reflect a culture in which they use the 'clinical term' in inverted commas to represent feelings that are denied.

Such narratives are readily understood in terms of Goffman's back-stage challenges that are never revealed or made visible [1]. They are also part of what Mandela (2005) would have recognised as contributing to the players' developing internal philosophy of liberation that will enable them to see a world beyond the control of the professional game. The impact of a culture of denial, and of the feeling you have no power, is further revealed in the narrative 'suppressing the way you want to feel' and the 'stress of asking yourself'. These suggest that the threedimensional character of the professional footballer-its physical essence, its cultural essence and its internal philosophical essence-is rendered unimportant.

\subsection{Conclusions}

My research has been focused on three moments: the denial of the body as a lived experience, the denial of the culture of a sport that objectifies the body and the internal processes professional players use to get beyond the ([5], p. 4) mask and beyond 
Du Bois' ([2], p. 4) veil. As a qualitative study, it seeks the reality of the professional footballer's lived and interpreted experience of stress, denial, moving and transition. Summed up as the snowball effect of the profession, these experiences reflect unrevealed values embedded in the culture of the sport.

As a former player, I am not detached from these experiences. Indeed, I find in my position as a researcher that I am once again trying to co-exist and to conform, this time to the dimensional pressures of the culture of research. I am at risk of ceasing to be an advocate for the lived experiences of professional players but constrained by the research conventions of reliability and validity. In this research, I risk forsaking the sense of myself, everything that I once exchanged for the commodity status of being a professional footballer. Once again, I find myself falling into a dimension, the internal philosophical dimension, in which my cultural identity and the values that support empowerment are invisible. Research and professional football share this cultural void, a void in which the processes of value and cultural denial lead to a delusion about what is value and culture to me.

Acknowledgements There are currently new initiatives in hand aimed at addressing the mental health issues with which this chapter is concerned. My hope is that the experiences of the players reported in this chapter will endorse the importance of these initiatives and provide insights that may contribute to their success.

\section{References}

1. Goffman E. The presentation of self in everyday life. London: Penguin Book; 1956.

2. Du Bios WD. The souls of the black folk. Oxford, New York: Oxford University Press; 1903.

3. Rhoden WC. Forty million Dollar slaves: the rise, fall, and redemption of the black athlete. New York: Crown Hardcover; 2007.

4. Hawkins BJ. The new plantation: black athletes, college sports, and predominantly white NCAA institutions. New York: Palgrave MacMillan Press; 2010.

5. Fanon F. Black skin, white mask. London: Pluto Press; 1967.

6. Mandel N. The long walk home. The autobiography. Great Britain: Little, Brown; 1995.

7. Smith JA. Beyond the divide between cognition and discourse: using interpretive phenomenological analysis in health psychology. Psychol Health. 1996;11:261-71.

Open Access This chapter is licensed under the terms of the Creative Commons Attribution 4.0 International License (http://creativecommons.org/licenses/by/4.0/), which permits use, sharing, adaptation, distribution and reproduction in any medium or format, as long as you give appropriate credit to the original author(s) and the source, provide a link to the Creative Commons license and indicate if changes were made.

The images or other third party material in this chapter are included in the chapter's Creative Commons license, unless indicated otherwise in a credit line to the material. If material is not included in the chapter's Creative Commons license and your intended use is not permitted by statutory regulation or exceeds the permitted use, you will need to obtain permission directly from the copyright holder. 